\title{
The American and Irish Gothic Novels: From Gloom to Doom
}

\author{
Hassan Ali Abdullah Al-Momani ${ }^{1}$ \\ ${ }^{1}$ English Language and Literature Department, Tafila Technical University, Jordan \\ Correspondence: Hassan Ali Abdullah Al-Momani, English Language and Literature Department, Tafila \\ Technical University, Jordan. E-mail: hassan76us@yahoo.com
}

\author{
Received: February 9, 2017 Accepted: February 25, 2017 Online Published: February 28, 2017 \\ doi:10.5539/ells.v7n1p106 URL: http://doi.org/10.5539/ells.v7n1p106
}

\begin{abstract}
The main purpose of this paper is to highlight the gloomy atmosphere in the American and Irish gothic novels as a reaction to the introspection of the dark side of the human nature and the ideological conflict or clash with other human groups. In this paper, a comparative close reading analysis will be implemented on Brown's Edger Huntly and Melville's Moby Dick from the American gothic novels, and on Maturin's Melmoth the Wanderer from the Irish literature, in order to prove how the gloomy atmosphere is one of the basic elements in the American and Irish gothic novels.
\end{abstract}

Keywords: gothic, gloom, doom, dark human nature, ideological conflict, violence

\section{Introduction}

One of the characteristics of the gothic novels is the depiction of the dark or gloomy side of the human nature. This dark side in most gothic novels is hard to justify because it is still unknown to the psychologists. However, the gloomy side of the human nature may be a reaction to the psychological, social, economic, ideological, and political unrest, or even to the human desire to survive in this nature. Such dark feeling might lead the characters in the gothic novel to violence, terror, murder, and loneliness. This psychological abnormality is related to the character's dark feeling of revenging upon others or upon the nature in order to assert his/her existence in the universe. This gloomy feeling lead the characters in the gothic novel to doom in which they are either die or get desperate and hopeless of their lives.

The genre of gothic has been tackled by many critics and writers who identify the features of this genre. For example, Eve Kosofsky Sedgwick (1986) outlined the features of gothic genre, in which the setting will include "an oppressive ruin" in "a wild landscape;" [there] will be "a heroine conspicuous for her "trembling sensitivity"...will be "a tyrannical older man..." "unnatural echoes or silences" and the "poisonous effects of guilt and shame" (qtd. in Correa \& Davies, 2004, p. 91).

Correa \& Davies (2004) emphasize the relationship between the gothic genre and the "literature of horror" (p. 93). The writers point out that the gothic genre is related to the term "uncanny" which "is not, of course, an effect exclusive as Gothic literature, but is an element within numerous genres" (p. 94). The term "uncanny" was defined by Bennett \& Royle (1995) as it "has to do with a sense of strangeness, mystery or eeriness...it concerns a sense of unfamiliarity which appears at the very heart of the unfamiliar... The uncanny is not just a matter of the weird or spooky, but has to do more specifically with a disturbance of the familiar" (qtd. in Correa \& Davies, 2004, p. 94).

Hume (1969) defines the gothic genre by saying that the gothic novels include "haunted castles, supernatural occurrences..., secret panels and stairways, time-yellowed manuscripts, and poorly lighted midnight scenes" (p. 282). Additionally, Dryden (2012) claims that the protagonists in the gothic novels "are mixed with horror and romance;" the gothic novels are "set in limited space, timeless and placeless, long time family secrets" (p. 18). The writer adds that the gothic novels are filled in "generations' curses, monsters, supernatural and mysteries [that] in the end or still leave the readers confusions and self-examination" (p. 18).

This paper is an exploration of this gloomy atmosphere in two American novels: Brown's Edger huntly and Melville's Moby Dick, and in the Irish novel Melmoth the Wanderer by Maturin. The goal of this discussion is to see explore the characters' gloomy feeling and how it leads to their doom at the end. 


\section{Discussion and Analysis of the Novels}

Edger Huntly can be considered as a gothic novel like other gothic ones which "emerged with all its furniture of ghosts, vaults, living statues, and family curses,... with its stress on the fantastic, the supernatural, and the macabre, and its props of haunted castles, graveyards, and ruins" (Kershner, 1997, p. 8). Additionally, Edger Huntly reflects the terror and violence that Brown tries to depict to reflect the gloomy and cruel part of the human nature.

Brown in Edger Huntly depicts how human nature influences one's acts which might motivate the human to commit crimes and harms others. In other words, the writer wants to convey a message to readers that it is impossible to resist the power of human nature on our acts. This depiction of human nature is like a journey from despondency to despair, in which when we delve into our human nature we become desperate because of discovering the evil or gloomy side of this nature. This gloomy or evil side motivates humans like Edger Huntly to become violent and aggressive with others in order to survive.

Thus, it is clear in this novel that Brown wants to assert a fact that the struggle for existence which is a natural law is controlled by human nature. This is clear in Edger Huntly's behaviors when he kills the Indians and revenge upon them in order to survive. From the beginning, Edger Huntly is motivated by his desire to find the person who kills his friend Walegrave who has died mysteriously. He suspects Clithero'sbehaviours which reflect how desperate he was because of sins. Edger was unable to evaluate Clithero's acts which reflect his psychological status that leads him to become a sleepwalker as an attempt to forget about his harmful deeds against others.

In other words, Edger is highly obsessed with knowing who killed his friend. In his quest, he is unable to move "from uncertainty to knowledge" (Brown, 1988, p. 6) because of irrationality that leads him to become violent against Indians and to kill them. Because of his failure to become rational in his judgments of others and of killing others, be becomes doomed at the end of the novel.

Additionally, Edger has an internal conflict in his psyche or nature, in which he becomes rational and irrational. In other words, he adopts certain social attitudes in his psyche that makes him wonder "was it proper to...rush upon him and extort from him, by violence or menaces, any explanation of the scene" (Brown, p. 10). In other words, Edger's nature has a good side which makes him refuse any violent act against others. This attitude reflects his rationality that is not influenced by ideological conflict with others. Even he refuses to make violence against others in the beginning of the novel: "What does vengeance desire but to inflict misery" (Brown, p. 24). Edger's ideology against violence here reflects the good side of his human nature which makes him unable to explain how Clithero attempts to kill the woman he loves. He considers such act irrational.

However, this good side of Edger's human nature changes into a gloomy one when he thinks of revenging upon the murderer of his parents. In his thinking of revenge, he has an internal psychological conflict between the rational attitudes he adopts and gloomy or dark motives of revenge: "You expect that, having detected the offender, I will hunt him to infamy and death. You are mistaken." (Brown, p. 31). In other words, Edger's ideology stored in his psyche is highly tied to rationality and his observation of the society which refuses the act of revenge.

Edger's human gloomy side results from the ideological clash or conflict with the Indians and from his attempt to survive in the nature. When he loses his feeling of consciousness and becomes a sleepwalker, he becomes controlled by animal nature. He kills the panther that attacks him and drinks his blood saying "The first suggestion that occurred to me was to feed upon the carcass of this animal" (Brown, pp. 159-160). In other words, Edger's gloomy side of his nature is a result of his desire to survive. He is controlled by the law of nature, in which "[his] doom was ratified by powers which no human energies can counterwork" (Brown, p. 78). I think that the dark side of Edger's nature is justified here because of his attempt to survive in the nature. Edger is obliged by the law of nature to defend himself against any power that threatens his life and existence.

Although Edger is tied to the law of nature in his attempt to survive, he has an internal conflict between rationality (the good side of his human nature) and irrationality (the gloomy or dark side of his nature). In other words, he gets confused when he finds the three Indians sleeping by fire. Although he has an ideological conflict with them and has the revenge desire to kill them, he attempts to avoid them and not to kill them. But this rational behavior does not last for a long time because he is governed by his gloomy thinking that motivates him to kill the guard in order to free the white girl. Here it should be emphasized that Edger, in his killing of the Indian, reflects his clash with the other. In other words, he is biased to his white race in his battle with the Indians. 
Again, Edger's gloomy side of his nature when he kills the Indian conflicts with his good side of his nature which refuses to kill or harm others: "Never before I had taken the life of a human creature. On this I had, indeed, entertained somewhat of religious scruples. These scruples did not forbid me to defend myself, but they made me cautious and reluctant to decide. Though they could not withhold my hand when urged by a necessity like this, they were sufficient to make me look back upon the deed with remorse and dismay" (Brown, p. 172). Thus, this quotation reflects Edger's internal conflict in his nature between the good side and the gloomy one.

Again, Edger's gloomy nature is obvious when he revenges upon the Indians when he finds the musket in their hut belongs to his uncle. His irrationality results from his unconscious thinking that Indians are the other who must be killed: "I was somewhat comforted in thinking that thus much of necessary vengeance had been executed" (Brown, p. 179). As a result, his gloomy nature represented in his revenge motivates him to kill two Indians. He loses his sense of rationality and self-control but he reflects his depression of returning to his gloomy nature: "the transition I had undergone was so wild and inexplicable" (Brown, p. 186).

The most horrible incident of Edger's gloomy nature is represented in his killing of the injured Indian creeping on a path. This act reflects how Edger is motivated by his inhuman thinking and irrationality. It seems that he is highly controlled by the animal instinct that made him kill the Indian badly.

Edger's despair results from his inability to explain the gloomy side of his nature that makes him blind to discover the inner truth in things around him. He wonders "how little cognizance has men over the actions and motives of each other! How total is our blindness with regard to our own performances" (Brown, p. 268). This despair reflects the internal conflict in Edger's psyche which makes him unable to clarify the gloomy side of human nature. In other words, Edger wants to convey a message to reader that we are victims of the gloomy side of our nature. He regrets that he was insane and gloomy: "I review this scene with loathing and horror. Now that it is the past I look back upon it as on some hideous dream. The whole appears to be some freak of insanity" (Brown, p. 160). Thus, Edger wants to tell readers that at certain moments of our life we might lose our rationality and the good side of our human nature and become insane and inhuman. He is so realistic in his depiction of the human nature that has this conflict between the good side and the gloomy one.

Furthermore, from a cognitive point of view, ideology which is stored in one's long term memory and related to the shared knowledge of a certain social group influences the human's behaviors. This may explain the ideological conflict between Edger and the Indians, in which there is no common ground between Edger and the Indians, so there is an ideological and cultural clash between Edger and the Indians. Although Edger has an internal conflict between his desire to revenge and his rational human thinking, he finds himself driven by his gloomy nature which is motivated by revenge desire and the law of nature. In other words, what makes Edger's gloomy side obvious is his thinking of the principle of the struggle for existence.

Edger is doomed at the end of his journey when he discovers his gloomy nature. He is shocked of this gloomy side of his nature and his violence. That is why he is desperate of his nature at the end of the story. It should be emphasized here that the Brown intends of writing this story to convey a message to all humans in the world that there is a dark or gloomy side of our nature that is hard to explain. He does not want to justify Edger's violent acts against the Indians, but he stresses the fact that in our life we might become a victim of our gloomy nature unconsciously when we feel that we are at danger.

Additionally, Brown in his depiction of Edger's psychological journey wants to draw the attention of readers that the law of nature always governs our own behaviors and turns us from being rational into being irrational. Thus, the writer's message in this story is humanitarian, in which all humans are subject to the law of struggle for existence. It is true that Brown in his depiction of Edger's personality reflects the ideological conflict between the white Americans and the Indians, but he tries to reconcile with the Indians when he states that Edger is controlled by natural law. Edger's internal conflict of being rational and irrational reflects the tone of reconciliation in Brown's psyche with the other (Indians). In short, Brown does not intend to beautify the image of Americans in their opposition with the Indians, but he wants to emphasize the humans have two sides in their nature: the good one and the gloomy side. And whatever we do to hide this gloomy side, we find ourselves victims of it.

Similarly, the gloomy atmosphere is obvious in Melville's Moby Dick (2001). Captain Ahab, the protagonist of the novel, reflects the dark side of his human nature in his quest of revenge upon Moby Dick. Although he knows that nature cannot be battled, he insists on his war against it. He has no ability to listen to others' minds and negotiate with them about his quest. It is clear from the very beginning of the novel that gloom surrounds Ahab's quest for revenge because he is driven by his craziness and single mindedness.

Additionally, Ahab's overconfidence is a clear hint to the readers that the story is a journey from gloom to doom. 
He wants to battle with the forces of nature without caring to the disastrous consequences of this battle. Instead of listening to Ishmael's wise advice of not chasing the white whale, Ahab wrongly believes that he is right in his quest to get rid of the evil of the world represented in the white whale. Even he thinks that he is fated to pursue the white whale and to kill it: "To me, the white whale is that wall, shoved near to me... He tasks me; he heaps me; I see in him outrageous strength, with an inscrutable malice sinewing it. That inscrutable thing is chiefly what I hate; and be the white whale agent, or be the white whale principal, I will wreak that hate upon him. Talk not to me of blasphemy, man; I'd strike the sun if it insulted me" (Melville, p. 162). Thus, it seems clear that the gloom in this novel result from Ahab's irrational thinking of defeating nature represented in the great power of the white whale.

Surprisingly, Ahab's gloomy nature increases when he defies the power of God when he says "who's over me? Truth hath no confines... What I've dared, I've willed; and what I've willed, I'll do!” (Melville, pp. 162, 166). Thus, the doom in the novel is predictable through Ahab's id that leads his crew to the destruction. Additionally, Ahab's irrational thinking of defying God makes him blind to know his limited capabilities as a human being. He thinks that his will is over God's will which is insanity.

In contrast with Ishmael's character who always views the inner truth of things, Ahab is driven by his hatred, revenge, and overconfidence. Ishmael's view about Ahab that he "piled upon the whale's white hump the sum of all the general rage and hate felt by his whole race from Adam down" (Melville, p. 200) reflects Ahab's problem and doom at the end, in which his inability to discover the truth of things leads him to destruction.

Ahab is doomed because of his single mindedness that makes him unable to think rationally. He also views the superficial side of things in life: "if man will strike, strike through the mask! How can the prisoner reach outside except by thrusting through the wall? To me, the white whale is that wall, shoved near to me. Sometimes I think there's naught beyond. But its enough" (Melville, p. 178). Thus, Ahab does not recognize the risks of questing the white whale because he is driven by his narrow mindedness.

Furthermore, Captain Ahab's gloom comes from his wrong belief that getting to the reality requires a confrontation with the enemy. This is what he did in his search to kill the white whale. He does not know about the power of the white whale and believes that he can defeat it because he is more powerful than it. Even he does not believe all the legends about the whale and its great power. The problem with Ahab is that he cannot recognize that the white whale is great power that cannot be battled.

Ahab's problem intensifies when he thinks that he is equal to the power of God and the whale. He is an irreligious person who is not obedient to the laws of God. Ahab is driven by his belief that his will is over God's will and over the power of fate. That is why he is doomed at the end of the story because of his madness and hatred. Unlike Ishmael who is the survivor at the end of the story because of his ability to delve into the deep truth of things, Ahab loses his battle with the white whale because of his defiance of the great power of nature and because of his limited knowledge of nature. Ahab is "the monster of intellect, destroys himself and his crew because he would "strike through the mask" in his insane compulsion to understand the eternal and unfathomable mystery of creation. Ishmael alone is saved because, through the wholesome influence of Queequeg, a Polynesian prince, he has acquired the primitive mode of accepting this divine mystery without question or hostility" (Guerin et al., 1965).

Similarly, the Irish gothic novelist Maturin reflects the gloomy side of the human nature in his novel Melmoth the Wanderer. The writer's gloomy depiction is due to his poverty and financial problems in life. He was responsible of taking care of his family and his old father (Ragaz, 2006). Regina Oost (1995) claims that Maturin was writing Melmoth the Wanderer for gaining money in order to overcome his economic problem. She clearly points out that Maturin has to "compromise his clerical reputation by taking up a pen" (p. 291). Oost adds that Maturin refers to Maturin's preface, in which he reveals his depression of being unaccepted by his audiences, readers, and critics who do not easily accept a clergyman who writes fiction (p. 291). However, although Maturin was motivated by his financial problem in writing his novel, Smith (1993) claims that the character of Wanderer in this novel enables the writer to create many suffering characters in the novelwho resemble the writer's suffering (p. 524).

From the very beginning of the novel, we feel the gloom represented in Wanderer's character who finds himself in a great problem. His problem lies in his quest to get rid of cruel wanderings. He helps the people who suffer from their dark life and tries to make them get rid of their sufferings in order to help him become free. Melmoth wants his victims to "writhe with all the impotent agony of an incarcerated mind" (Maturin, 2000, p. 285).

The gloomy atmosphere in the novel results from the suffering of the characters which hints to the writer's. The suffering of the storytellers of the novel Biddy Brannigan and Walberg reflects how some people in the society 
might be victims of the social injustices and the hard economic problems. Both the storytellers were victims of the social hypocrisy which obliged them to be deceptive. Additionally, the storytellers are victims of the social injustice that obliged the poor to be controlled by the rich in order to make their living (Oost, p. 291). Thus, it is noticed that Maturin's creation of suffering characters reflects his refusal of the social injustice and his message to the readers that he was obliged to write this novel to overcome his financial problem. Furthermore, Maturin seems to believe that "the drama of terror has the irresistible power of converting its audience into its victims" (Maturin, p. 257). Thus, the whole novel seems to be a journey from gloom to doom.

The gloomy atmosphere in Melmoth the Wanderer (2000) is obvious in Maturin's refusal and criticism of the political and religious authorities. The writer seems uncomfortable with the corruption of these authorities. Moncada who was one of the monks reflects how they harmed and tortured a young novice:

A naked human being, covered with blood, and uttering screams of rage and torture, flashed by me; four monks pursued him-they had lights... The victim reached the door, found it shut, and rallied...He stood in an attitude of despair-he was streaming with blood. The monks, with their lights, their scourges, and their dark habits, seemed like a group of demons who had made prey of a wandering angel (p. 83).

Thus, Maturin reflects the gloom represented in the corruption of the religious authority, in which the monks victimize the people and make them suffer.

Another gloomy picture in this novel represented in the cruelty and tyranny of kings who were unfair in their treatment of the poor: "people have made unto themselves kings, that is, beings whom they voluntarily invest with the privilege of draining, by taxation, whatever wealth their vices have left to the rich, and whatever means of existence their want has left to the poor, till their extortion is cursed from the castle to the cottage" (p. 233). In sum, Maturin blames the king's corruption which leads the people to suffer. Even Melmoth in this novel criticizes the king's evil in making wars which serve their agendas to subjugate and humiliate the people: "kings amuse themselves by making war, that is, collecting the greatest number of human beings that can be bribed to the task, to cut the throats of a less, equal, or greater number of beings... hatred is their duty, and murder is their delight" (p. 233). Thus, this gloomy description of the tyranny and cruelty of the kings who made the poor suffer and the rich to entertain reflects how desperate Maturin was toward the political authority in his time.

Maturin on the tongue of Melmoth reveals how the kings entertain the suffering of the people. This is clear when Immallee asks "why should some have more than they can eat and others nothing to eat," Melmoth replies her:

This... is the most exquisite refinement on that art of torture which those being beings [those in power] are so expert in-to place misery by the side of opulence-to bid the wretch who dies for want feed on the sound of splendid equipages which shake his hovel as they pass, but leave no relief behind (p. 232).

Thus, it is clear from the previous quotation that the gloomy life the suffering people lived is due to the kings' interest in torturing the people and making them suffer without showing them any human feeling. This is clear evidence that Maturin's financial problem is caused by the selfishness and corruption of the kings that made the poor people poorer.

Another gloomy picture in the novel related to the corruption of religious authority is when Moncada wants to leave the monastery because of his refusal of this corruption. He depicts to us how the monks are inhuman with their treatment of the monk whose sin that he falls in love with a woman and marries her. This monk's punishment is the prison until he dies. Moncada reveals the gothic atmosphere related to the Inquistion, in which he experiences the torture by the monks: "I awoke one night, and saw my cell in flames, I started up in horror, but shrank back on perceiving myself surrounded by demons, who clothed in fire, were breathing forth clouds of it around me. Desperate with horror, I rushed against the wall, and found what I touched was cold" (p. 118). Thus, Moncada's despair to get rid of the monastery reflects how his life is a journey from despondency to despair, in which it is hopeless to get rid of the religious corruption.

Additionally, Immallee's despair results from her frustration with the European civilization which is depicted in a gloomy image: "I am so ignorant in this new world, I have so much to learn, my senses so often deceive me" (p. 264). She is hopeless in this modern world which is full of corruption. Even she is desperate about her child in this world who is "alone, unaided, unsustained, unconsoled" (p. 390). When her child dies, Immallee becomes doomed and desperate: "Oh that I had loved none but God- how profound would have been my peace-how glorious my departure-now-his image pursues me even to the brink of the grave, into which I plunge to escape it!" (p. 405).

Furthermore, Melmoth is doomed at the end. His despair and gloomy fate is obvious at the end of the novel: "no hope-but that of plunging others into his own condemnation. No fear-but that his victim might escape him" (p. 
241). Melmoth is shocked of the gloomy side of human nature. He suffers from his loneliness because he finds no hope in life:

Accustomed to look on and converse with all things revolting to nature and to man, forever exploring the mad-house, the jail, or the Inquisition, the den of famine, the dungeon of crime, or the death-bed of despair, hiseyes had acquired a light and language of their own- a light that none could gaze on, and a language that few dare understand (p. 249).

Thus, it seems clear from the previous quotation that Melmoth loses the hope in life because of the injustices he witnessed.

Melmoth's last cry on the edge of Hell is so gloomy. He says "Mine was the great angelic sin-pride and intellectual glorying! It was the first mortal sin- a boundless aspiration after forbidden knowledge... remember your lives will be the fortfeit of your desperate curiosity. For the same stake I risked more than life- and lost it! Be warned- retire!" (pp. 380, 411). Thus, it is clear that Melmoth fails to find justice and mercy in the world, that is why he expresses his despondency when he says "no one has ever exchanged destinies with Melmoth the Wanderer. I have traversed the world in the search, and no one to gain that world, would lose his soul... My hour is come... It is an hour you must neither partake or witness-the clock of eternity is about to strike, but its knell must be unheard by mortal ears" (pp. 601-604).

\section{Conclusion}

Finally, it can be concluded that after this discussion of the American and Irish gothic novels that they all reflect the gloomy atmosphere which is a reflection of the dark side of the human nature. All the previous novels start from this gloomy depiction of the human psyche that may be related to the desire of revenge and the ideological conflict with the Indians as in Edger Huntly, or to the craziness of questing and battling with nature and revenging upon it as in Moby Dick, or to react against the corruption of political and religious authority which leads Melmoth the Wanderer to reflect his suffering and despair. In short, all the three novels share the gloomy picture of the human nature which is represented in the characters' unconscious and uncontrolled behaviors, violence against others, and terror. This gloomy atmosphere leads to the doom in the three novels which is represented in the characters' loss of hope and despair or death.

\section{References}

Bennett, A., \& Royle, N. (1995). An Introduction to Literature, Criticism and Theory. Birmingham: Harvester Wheatsheaf.

Brown, C. (1988). Edger Huntly or, Memoirs of a Sleep-Walker. Canada: Penguin Books.

Correa, D., \& Davies, J. (2004). Reading Jane Eyre. In D. Walder (Ed.), The Realist Novel. England.

Dryden, L. (2012). Comparison of Gothic Genre in both English and Chinese Fictions. International Journal of Social Science and Humanities, 1(1), 18-25.

Guerin, L. et al. (1965). A Handbook of Critical Approaches to Literature. New York: Harper and Row Publishers.

Hume, R. (1969). Gothic versus Romantic: A Revaluation of the Gothic Novel. PMLA, 84(2), 282-290. https://doi.org/10.2307/1261285

Kershner, R. (1997). The Twentieth-Century Novel: An Introduction. New York: Bedford Books.

Maturin, C. (2000). Melmoth the Wanderer. London: Penguin Books Ltd.

Melville, H. (2001). Moby-Dick: An Authoritative Text (2nd ed.). New York: W. W. Norton.

Oost, R. B. (1995). "Servility and command": Authorship in Melmoth the Wanderer. Papers on Language and Literature, 31(3), 291.

Ragaz, S. (2006). Maturin, Archibald Constable, and the Publication of Melmoth the Wanderer. The Review of English Studies, 57(230), 359-373. https://doi.org/10.1093/res/hg1042

Sedgwick, K. (1986). The Conference of Gothic Conventions. Methuen.

Smith, A. E. (1993). Experimentation and "horrid curiosity" in Maturin's Melmoth the Wanderer. English Studies, 74(6), 524. https://doi.org/10.1080/00138389308598885 


\section{Copyrights}

Copyright for this article is retained by the author(s), with first publication rights granted to the journal.

This is an open-access article distributed under the terms and conditions of the Creative Commons Attribution license (http://creativecommons.org/licenses/by/4.0/). 